\title{
Da teoria à prática: a importância de se publicar em medicina de equídeos
}

\author{
Helio Cordeiro Manso Filho ${ }^{1}$, Rui Carlos Vincenzi ${ }^{2}$ \\ ${ }^{1}$ Universidade Federal Rural de Pernambuco (UFRPE), Recife, PE, Brasil \\ ${ }^{2}$ Presidente da Associação Brasileira de Médicos Veterinários de Equídeos (Abraveq), Rio Preto, SP, Brasil
}

O lançamento de cada número de uma revista científica na área da Medicina Veterinária é sempre algo a ser comemorado com entusiasmo, pois favorece o desenvolvimento e treinamento dos profissionais médicos veterinários e, nesse caso, dos profissionais de equinos ou hipiatras.

Além do entusiasmo, estamos muito honrados em poder fazer o editorial desta edição temática de Medicina de Equídeos que a Revista Acadêmica: Ciência Animal está publicando. Esse volume contribui para à construção de novos conhecimentos e para a divulgação de resultados que não podem ficar restritos a poucos, pois só assim a ciência completa o seu ciclo, com a incorporação dos novos conceitos às práticas diárias através de publicações em revistas científicas.

A Revista Acadêmica: Ciência Animal propicia a possibilidade de dar ciência ampla e irrestrita à sociedade em geral, advinda dos resultados de estudos e pesquisas de grupos de diferentes regiões do país, como também de profissionais que reconhecem a importância de compartilhar experiência de campo e casuística. Ela atende, ainda, a finalidades basilares tanto da academia, nesse caso da Pontifícia Universidade Católica do Paraná, como também da Associação Brasileira de Médicos Veterinários de Equídeos (ABRAVEQ), que é de estimular a produção cientifica e de promover a sua disseminação, levando informações ao maior número de profissionais, que poderão utilizar este conhecimento na sua rotina diária.

Esperamos que os leitores da revista aproveitem esta diversidade de artigos, pela qualidade, atualidade e relevância dos temas tratados, sobre áreas extremamente importantes na medicina veterinária equina. E que também esses trabalhos sirvam de inspiração e referência para novas publicações. 